\title{
The herpes simplex virus trans-activator VP16 recognizes the Oct-1 homeo domain: evidence for a homeo domain recognition subdomain
}

\author{
Seth Stern and Winship Herr \\ Cold Spring Harbor Laboratory, Cold Spring Harbor, New York 11724 USA
}

\begin{abstract}
The homeo domain of the Oct-1 transcription factor directs formation of a multiprotein-DNA complex containing Oct-1, the herpes simplex virus (HSV) trans-activator VP16, and a second host cell factor (HCF). This VP16-induced complex alters the regulatory activity of Oct-1, in part, by associating it with the potent VP16 acidic transcriptional activation domain. Here, we show that in the absence of HCF, VP16 can recognize specifically the Oct-1 homeo domain. A region of VP16 near the acidic activation domain appears to be involved exclusively in homeo domain recognition because a 4-amino-acid insertion within this region only affects the ability of VP16 to interact with Oct-1, leaving its DNA- and HCF-binding activities unchanged. A 33-amino-acid peptide containing this region complexes with the Oct-1 POU domain bound to DNA, suggesting that this VP16 region contains an autonomous homeo domain recognition subdomain.
\end{abstract}

[Key Words: VP16; Oct-1; homeo domain; transcription]

Received September 19, 1991; revised version accepted October 10, 1991.

Homeo domain proteins are important regulators of gene transcription during development, but the mechanisms by which they control transcription are only beginning to be understood in detail (for review, see Hayashi and Scott 1990). The homeo domain is a tri- $\alpha$-helical DNAbinding domain, similar in structure to the helix-turnhelix motif of prokaryotic repressor proteins such as $\lambda$ repressor (Qian et al. 1989; Kissinger et al. 1990). It has frequently been observed that homeo domains exhibit overlapping DNA-binding specificities in vitro that appear inconsistent with the highly specific effects conferred by homeo domain proteins in vivo. Nonetheless, in Drosophila embryos, the homeo domain, rather than flanking protein regions, is largely responsible for promoter selectivity (Kuziora and McGinnis 1989; Gibson et al. 1990; Malicki et al. 1990; Mann and Hogness 1990; McGinnis et al. 1990). These observations suggest either that subtle differences in DNA-binding specificities are sufficient to produce strong promoter selectivity in vivo or that protein-protein interactions involving homeo domains introduce additional binding or activation specificities.

Properties of the DNA-binding domains of both $\lambda$ repressor and the human homeo domain protein Oct-1 (also referred to as OTF-1 and NFIII) show that the helixturn-helix motif and the homeo domain can indeed participate in selective protein-protein interactions that regulate transcription. The helix-turn-helix motif of $\lambda$ repressor, in addition to binding DNA, is responsible for activating transcription from the phage promoter $P_{\mathrm{RM}}$.
Amino acids within the helix-turn-helix motif involved in transcriptional activation do not appear to interact with DNA (Guarente et al. 1982; Hochschild et al. 1983); instead, they are thought to activate transcription by contacting RNA polymerase (Hawley and McClure 1983). The site of interaction within RNA polymerase, however, is not known. Amino acids in the Oct-1 homeo domain that are not directly involved in DNA binding similarly regulate transcription, as they direct formation of a multiprotein-DNA complex containing the herpes simplex virus (HSV) protein VPl6 (Stern et al. 1989). This complex, which has been termed the VP16-induced complex, activates HSV immediate-early (IE) gene transcription (for review, see Goding and O'Hare 1989); but as is the case with the $\lambda$ repressor helix-turn-helix motif, the protein target of the Oct-1 homeo domain in these interactions has not been identified.

VP16 (also referred to as Vmw65 and $\alpha$-TIF) is a component of the HSV virion (Batterson and Roizman 1983; Campbell et al. 1984). Upon infection of the host cell, VP16 forms the VP16-induced complex on TAATGARAT sequence elements in the IE gene promoters of HSV (McKnight et al. 1987; O'Hare and Goding 1988; Preston et al. 1988). In addition to VP16, this complex contains Oct- 1 and a second less well-characterized host cell factor, which we refer to as HCF /Gerster and Roeder 1988; apRhys et al. 1989; Kristie et al. 1989; Katan et al. 1990; Xiao and Capone 1990; also referred to as C1, VCAF, and CFF). VP16 contains a potent carboxy-terminal acidic activation domain (Sadowski et al. 1988; Triezenberg et al. 
1988; Cousens et al. 1989) that, although not required to form the VP16-induced complex (Greaves and O'Hare 1989; Kristie et al. 1989; Werstuck and Capone 1989b), strongly activates HSV IE and related promoters $1 \mathrm{O}^{\prime}$ Hare and Goding 1988; Tanaka et al. 1988; Triezenberg et al. 1988). Because Oct-1 does not readily activate these mRNA-type promoters in the absence of VP16 (Tanaka et al. 1988), VP16 acts as a transcriptional adaptor that alters the promoter selectivity of Oct-1, allowing it to stimulate a new set of promoters.

The TAATGARAT elements of HSV are frequently overlapped by sequences with similarity to the octamer motif (Pruijn et al. 1986; apRhys et al. 1989), yielding the sequence ATGCTAATGARAT (octamer underlined), which we refer to as an OCTA $^{+}$|TAATGARAT sequence. The octamer motif is recognized by Oct- 1 , a member of the POU class of homeo domain proteins, which also includes the B-cell transcription factor Oct-2 (OTF2) and the pituitary factor Pit-1 (GHF-1) (Herr et al. 1988). POU-class transcription factors contain a highly conserved 160-amino-acid bipartite DNA-binding domain composed of a carboxy-terminal homeo domain and an amino-terminal POU-specific region (Herr et al. 1988; Sturm and Herr 1988). The POU domains of Oct-1 and Oct-2 are closely related (Clerc et al. 1988; Sturm et al. 1988) and exhibit very similar, if not identical, DNAbinding specificities (Staudt et al. 1986). But the Oct-1 and Oct-2 proteins display distinct transcriptional specificities: Only Oct- 2 readily activates a broad set of mRNA promoters (Tanaka and Herr 1990) and only Oct-1 is readily incorporated into the VP16-induced complex (Gerster and Roeder 1988). Oct-2 fails to form a complex with VP16 because the Oct- 2 homeo domain differs from the Oct-1 homeo domain at 7 of 60 positions (Stern et al. 1989). These amino acids are thought to be exposed to solvent when the homeo domain is bound to DNA and are thus available to interact with other proteins in the VP16-induced complex (Stern et al. 1989; see also Kissinger et al. 1990; Otting et al. 1990).

Although the Oct-1 homeo domain is both necessary (Stern et al. 1989) and sufficient (Katan et al. 1990; Kristie and Sharp 1990) to direct formation of the VP16induced complex, it has not been established whether VP16 or HCF is the target of the homeo domain in these interactions. Here, by assaying VP16-induced complex formation in the absence of HCF, we show that VP16 can discriminate between the closely related Oct-1 and Oct-2 homeo domains. In addition, using VP16 mutants and synthetic peptides, we have localized the homeo domain target region of VP16 to a position near its acidic activation domain. We present evidence suggesting that this target region constitutes a small independent VP16 subdomain involved exclusively in homeo domain association.

\section{Results}

In these studies wild-type and mutant VP16 proteins have been expressed in Escherichia coli as protein A fu- sions and purified from extracts with IgG-Sepharose beads. The carboxy-terminal 80 -amino-acid acidic transcriptional activation domain of full-length VP16, which is dispensable for VP16-induced complex formation (Greaves and O'Hare 1989; Kristie et al. 1989; Werstuck and Capone 1989b|, was deleted from all of these constructs. Wild-type Oct-1 POU domain, as well as a chimeric Oct-1 POU domain carrying the Oct-2 homeo domain (referred to as an Oct-1[Ho2] POU domain), have also been expressed in $E$. coli and were purified from extracts by DNA affinity chromatography (Kadonaga and Tijan 1986). Because HCF is normally required to observe VP16-induced complex formation, we sometimes refer to the VP16-induced complex formed with VP16, the Oct-1 POU domain, and HCF under standard conditions (see below) as the HCF-dependent VP16-induced complex. Complexes formed with the Oct-1 POU domain and VP16 in the absence of HCF are referred to as HCF-independent VP16-induced complexes. Below, wild-type VP16 and the two POU domain proteins have been used to establish that VP16 can specifically recognize the Oct-1 homeo domain in HCF-independent VP16-induced complexes; and mutant VP16 proteins, along with VP16-derived synthetic peptides, have been used to localize the homeo domain target region and to characterize its properties.

\section{HCF-independent recognition of the Oct-1 homeo domain by VP16}

Alone, VP16 does not interact efficiently with DNA (Marsden et al. 1987), and it has been thought that its association with specific cis-acting elements is entirely dependent on protein-protein interactions occurring in the VP16-induced complex. Recently, however, Kristie and Sharp (1990) showed that under some conditions VP16-DNA complexes can be observed in mobility-shift assays and that the interaction of VP16 with DNA appears to be stabilized by Oct-1. To establish that such HCF-independent Oct-1-VP16 interactions are relevant to the well-characterized HCF-dependent VP16-induced complex, we designed a mobility-shift assay to test whether, in the absence of HCF, VP16 can distinguish between the closely related Oct- 1 and Oct- 2 homeo domains while they and VP16 bind specifically to DNA. In these assays, the requirement for HCF has been overcome by using high concentrations of VP16 and assay conditions that stabilize the complexes (see Materials and methods).

In the mobility-shift assay shown in Figure 1A, increasing concentrations of VP16 were incubated with an OOCTA $^{+} \mid$TAATGARAT probe alone or along with either the Oct-1 POU domain or the chimeric Oct-1[Ho2] POU domain. When the Oct-1 POU domain (lane 2) or the Oct-1[Ho2] POU domain (lane 3) was incubated alone with the probe, the expected POU domain-DNA complexes formed. Addition of 10-fold more VP16 (10×, 0.5 $\mu \mathrm{g})$ than is normally used to form the HCF-dependent VP16-induced complex to the probe alone (lane 4) or to 
A

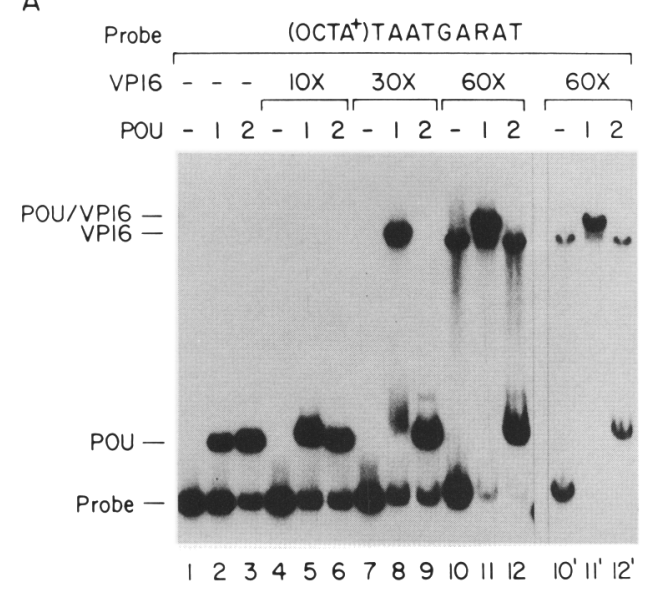

B

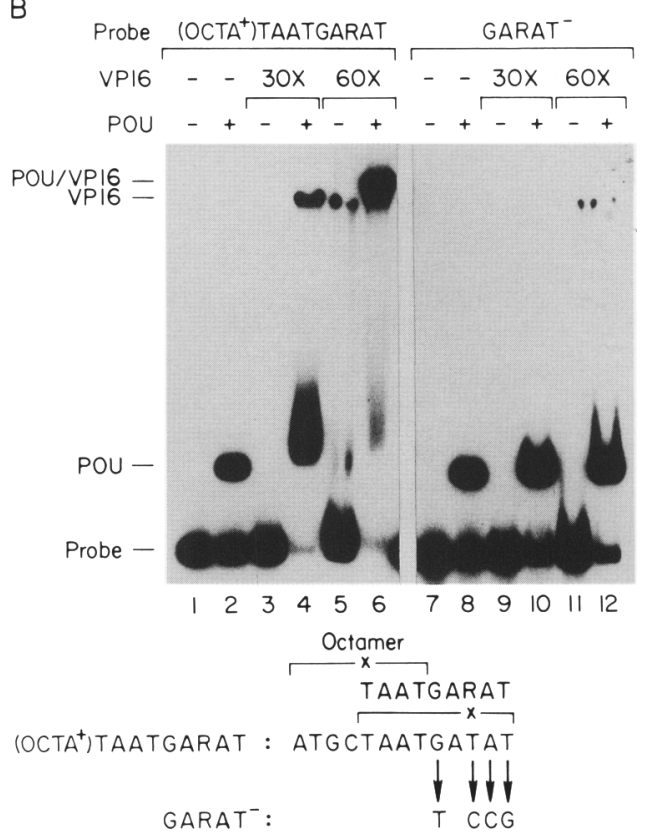

Figure 1. HCF-independent VP16-induced complexes with Oct-1 and Oct-1[Ho2] POU domains. $(A)$ Mobility-shift reactions with wild-type (OCTA ${ }^{+}$|TAATGARAT probe and increasing amounts of VP16 alone, or along with either the Oct-1 or Oct-1[Ho2] POU domain. The identity of the POU domain and the quantity of VP16 used in each reaction are shown above the gel. Either no POU domain (-1, Oct-1 POU domain \{1\}, or chimeric Oct-1[Ho2] POU domain (2) was used in these reactions as indicated. About 50 ng of E. coli-expressed protein A-VP16 fusion protein is normally used to generate the HCF-dependent VP16-induced complex. Here, either no VPl6 was added (-) or $500 \mathrm{ng}(10 \times), 1.5 \mu \mathrm{g}(30 \times)$, or $3 \mu \mathrm{g}(60 \times)$ of protein A-VP16 fusion protein was included in the reaction. A short exposure of lanes $10-12\left(10^{\prime}-12^{\prime}\right)$ is shown at right and the identities of the different complexes are indicated at left. $(B)$ Mobility-shift reactions with wild-type (OCTA ${ }^{+}$|TAATGARAT (lanes 1-6) and mutant GARAT ${ }^{-}$(lanes $7-12$ ) probes. Reactions without $(-)$ or with $|+|$ Oct-1 POU domain, and without $\mid-$ ) or with either $1.5 \mu \mathrm{g}(30 \times)$ or $3 \mu \mathrm{g}(60 \times)$ of protein A-VP16 fusion protein are indicated. The complexes are identified at left; the sequences of the wild-type and mutant TAATGARAT motifs are shown below.

the probe and either of the two POU domains (lanes 5 and 6) resulted in no new complexes. Addition of 30-fold more VP16 $(30 \times, 1.5 \mu \mathrm{g})$ by itself to the probe also resulted in no complex formation (lane 7); however, at this VP16 concentration, VP16 and the Oct-1 POU domain appeared to cooperate to produce a prominent new slowly migrating complex (lane 8), which we refer to as a POU domain-induced VP16-DNA complex (migrating between the POU/VP16 and VP16 labels). At the same time, the complex corresponding to the Oct-1 POU domain itself was attenuated, and the remainder was heterogeneously retarded in mobility (cf. lanes 5 and 8 ). The basis for this change in appearance is not fully understood (discussed below); however, formation of the upper POU domain-induced VP16-DNA complex is specific for the Oct-1 homeo domain, as no such complex formed when the Oct-1[Ho2] POU domain was used in an identical reaction (cf. lanes 8 and 9 ).

At a 60-fold higher than normal VP16 concentration $(60 \times, 3 \mu \mathrm{g}), \mathrm{VP} 16$ bound DNA on its own (lane 10), and the resulting complex migrated slightly faster than the POU domain-induced complex formed with $30 \times$ VP16 (cf. lanes 8 and 10). Addition of the Oct-1 POU domain to this $60 \times$ VP16 binding reaction resulted in the apparent supershifting of the VP16-DNA complex /cf. lanes 10 and 11 , and lanes $10^{\prime}$ and $11^{\prime}$ in the shorter exposure). This supershifted complex probably contains the Oct-1 POU domain, because when the POU domain was replaced by just the Oct-1 homeo domain a smaller supershift was observed (data not shown). Even at the $60 \times$ concentration VP16 continued to distinguish between the Oct- 1 and Oct- 2 homeo domains because substitution of the Oct-1[Ho2] POU domain in an identical reaction eliminated formation of the POU domain-VP16DNA supershifted complex (lane 12). Thus, the seven Oct-2-specific amino acids within the homeo domain interfere with the ability of the Oct-1 POU domain and VP16 to interact simultaneously with DNA, suggesting that precise and intimate contacts form between these three complex components.

Interestingly, while the POU domain-induced VP16DNA complex (formed at 30×, VP16, lane 8) and the POU domain-VP16-DNA complex (formed at 60x, VP16, lane 11) both migrated slower than the VP16DNA complex (formed at $60 \times$, lane 10), their mobilities were not identical /cf. upper complexes in lanes 8 and 11). This observation suggests either that their compositions differ or that their components have adopted different conformations that result in altered mobilities. Although the latter possibility cannot be ruled out, we 
favor the idea that the final position of the POU domaininduced VP16-DNA complex formed with $30 \times$ VP16 is the result of the decay during electrophoresis of an initially formed ternary POU domain-VP16-DNA complex into either a VP16-DNA or a POU domain-DNA complex. The resulting VP16-DNA complex will migrate faster than the stable POU domain-VP16-DNA complex formed with $60 \times \mathrm{VP16}$, explaining their relative positions in the gel. Additionally, if decay of the initially formed ternary complex takes place during an appreciable fraction of the electrophoretic run, the final position of the smaller POU domain-DNA complex will vary, explaining its heterogeneous distribution in lane 8 . In any case, the results in Figure $1 \mathrm{~A}$ clearly show that HCFindependent VP16-induced complex formation requires Oct-1 homeo domain sequences.

In addition to exhibiting specificity for the Oct-1 homeo domain, formation of the HCF-dependent VP16induced complex also requires GARAT-containing DNA sequences flanking the octamer motif in the (OCTA ${ }^{+}$|TAATGARAT element. Mutations within the GARAT subelement reduce VP16-induced complex formation without affecting the interaction of Oct- 1 itself with the probe (Gerster and Roeder 1988; O'Hare et al. 1988; Kristie et al. 1989). Because VP16, but not HCF, has been shown to bind specifically to GARAT containing DNA sequences (Kristie and Sharp 1990), these observations suggest that VP16 interacts with the GARAT subelement within the HCF-dependent VP16-induced complex. If we are correct in concluding that within the HCF-independent VP16-induced complexes shown in Figure 1A, VP16 specifically recognizes the Oct-1 homeo domain while it also interacts with DNA, then mutation of the GARAT subelement should disrupt selectively VP16-DNA interactions while leaving the interaction of the Oct-1 POU domain with DNA unchanged.

The experiment shown in Figure 1B, in which identical reactions have been repeated with a wild-type $\left(\mathrm{OCTA}^{+}\right)$TAATGARAT probe (lanes 1-6) or a mutant probe (lanes 7-12) containing four point mutations within the GARAT subelement (Gerster and Roeder 1988), shows that VP16-DNA interactions can be disrupted selectively. While binding of the Oct-1 POU domain itself to the mutant probe was undiminished (cf. lanes 2 and 81 , formation of the POU domain-induced VP16-DNA complex with $30 \times$ VP16 was not detectable (cf. lanes 4 and 10 ). At the $60 \times$ concentration level, however, VP16 formed a small amount of complex with the mutant probe (lane 11; VP16-DNA complexes in lanes 11 and 12 failed to form discrete bands and are visible only at the edges of the lanes). Unlike the VP16-DNA complex formed with the wild-type probe, however, formation of this VP16-DNA complex was not stimulated by the Oct-1 POU domain, nor was this complex supershifted by the Oct-1 POU domain (cf. lanes 5 and 6 with 11 and 12) These results suggest that although it is able to bind to the mutant probe, VP16 interacts aberrantly with it and, furthermore, that VP16 recognizes the Oct-1 homeo domain only when it can bind specifically to the GARAT subelement. Moreover, these results show that the previously observed specificities of the HCF-dependent VP16-induced complex, for the Oct-1 homeo domain and GARAT-containing DNA sequences, can be fully accounted for by the specificities of VP16 in the absence of $\mathrm{HCF}$, showing that $\mathrm{HCF}$ is not essential for normal Oct-1-VP16 interaction. The results of these experiments, therefore, serve to identify VP16 as the likely target of the Oct-1 homeo domain within the HCF-dependent VP16-induced complex.

\section{VP16 mutations affecting HCF, DNA, and Oct-1 interactions}

We then used VP16 mutants to characterize the interactions of the protein with its three ligands: HCF, DNA, and Oct-1. The results of these assays have allowed us to localize the target of the Oct-1 homeo domain within VP16. The structures of the four mutant VP16 proteins are shown in Figure 2, which also summarizes the results of these experiments. Previous mutagenesis studies (Ace et al. 1988; Werstuck and Capone 1989a,b; Greaves and O'Hare 1989, 1990) have identified two important regions for VP16-induced complex formation; we refer to these as region I (amino acids 173-241) and region II (amino acids 317-403). We constructed two mutants, RI- $\Delta$ and RII- $\Delta$, in which regions I and II are deleted individually. We also assayed the activities of two previously characterized 4-amino-acid insertion mutants, in 9 and in 14 (Ace et al. 1988), which we refer to here simply as RI-i and RII-i, respectively. These two mutations disrupt formation of the HCF-dependent VP16-induced complex; the RII-i mutant, however, can still participate in virion assembly, suggesting that its structure is not grossly altered (Ace et al. 1988).

To study the effects of the four mutations on VP16HCF interactions, we exploited the ability of VP16 to complex independently with HCF (Kristie and Sharp 1990; Xiao and Capone 1990; this study) in an HCF microprecipitation assay. HeLa cell nuclear extract was mixed with wild-type or mutant protein A-VP16 fusion protein, incubated for $30 \mathrm{~min}$ at $30^{\circ} \mathrm{C}$, and added to IgGSepharose beads, which bind the protein A moiety of the fusion proteins. The beads were washed, and proteins eluting with $1 \mathrm{~m} \mathrm{KCl}$ buffer (Xiao and Capone 1990) were monitored for HCF activity by assaying their abilities to promote formation of an HCF-dependent VP16-induced complex with Oct-1 POU domain and wild-type VP16 in a subsequent mobility-shift assay. In these reactions, the amount of VP16-induced complex formed in the mobility-shift assay reflects the amount of HCF eluting from the beads.

The first three panels of the mobility-shift assay shown in Figure 3 characterize this two-step HCF assay system. As shown in the first panel, the Oct-1 POU domain readily bound the OCTA $^{+} \mid$TAATGARAT probe (lane 2), and as expected under these conditions, VP16 did not bind the probe in the absence (lane 3 ) or presence (lane 4) of the Oct-1 POU domain. The second and third panels show that HCF activity was retained by the IgGSepharose beads in the presence (lanes 10-15) but not in 


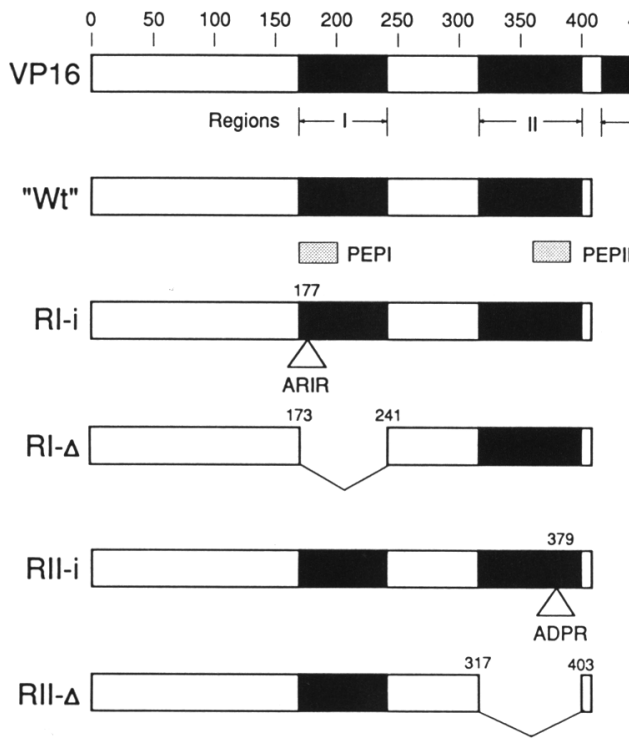

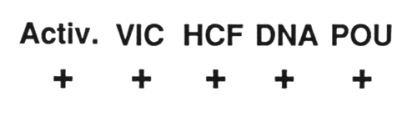

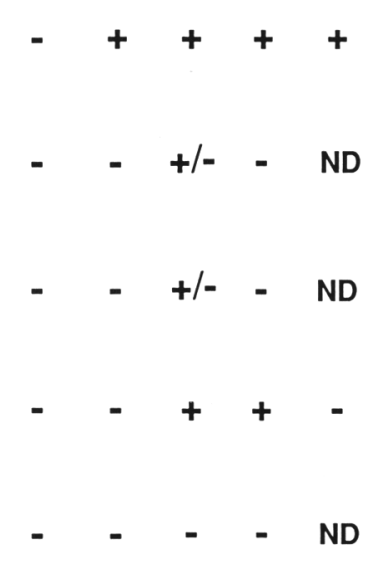

Figure 2. Structures and activities of wild-type and mutant protein A-VPl 6 fusion proteins. Wild-type VP16 contains 490 amino acids, with an 80-amino-acid carboxy-terminal acidic transcriptional activation domain (Activ.) that was deleted from the constructs used in this study. The wild-type protein lacking this domain is denoted "Wt." Two deletions were individually made in wild-type VP16: either region I, extending from amino acid 173 to 241 inclusive (RI- $\Delta$ ), or region II, extending from amino acid 317 to 403 inclusive (RII$\Delta$ ), was deleted. In addition, the previously described 4-amino-acid insertion mutations, in9 (after amino acid 177) and in 14 (after amino acid 379) (Ace et al. 1988), were introduced individually within regions I and II and are referred to here as RI-i and RII-i, respectively. The amino acids inserted by the in 9 and in 14 mutations are indicated below their respective positions. The positions of sequences contained in the region I-derived peptide PEPI and the region II-derived peptide PEPII are shown below wild-type VP16. PEPI contains amino acids 170-202 and overlaps in9, whereas PEPII contains amino acids 360-391 and overlaps in 14. Not shown is PEPII-i, which is identical to PEPII except that it contains the 4 -amino-acid in 14 insertion. The activities of each VP16 construct are shown at right. Four activities were monitored in this study: formation of an HCF-dependent VP16-induced complex (VIC), HCF binding (HCF), DNA binding (DNA), and complex formation with the Oct-1 POU domain in the presence of DNA (POU). ND indicates that the POU-binding activity of the protein was not determined because the VP16 mutant failed to interact with DNA.

the absence (lanes 5-9) of wild-type protein A-VP16 fusion protein. The HeLa cell nuclear extract used in the precipitation reaction contains both endogenous Oct-1 and HCF because it formed the expected Oct-1 complex with the probe (lane 5), and it formed a VP16-induced complex (labeled VIC) when wild-type VP16 was added without (lane 6) or with (lane 7) the Oct-1 POU domain. The eluate from a microprecipitation reaction performed without VP16 lacked endogenous Oct-1 (lane 8) and failed to form a VP16-induced complex when incubated with the Oct-1 POU domain and wild-type protein A-VP16 fusion protein (lane 9), showing that it does not contain HCF activity. When wild-type protein A-VP16 fusion protein was included in the microprecipitation reaction the eluate again lacked endogenous Oct-1 (lane 12 , and it also failed to form a VP16-induced complex when either the Oct-1 POU domain (lane 13) or VP16 (lane 14) was added individually. When the Oct-1 POU

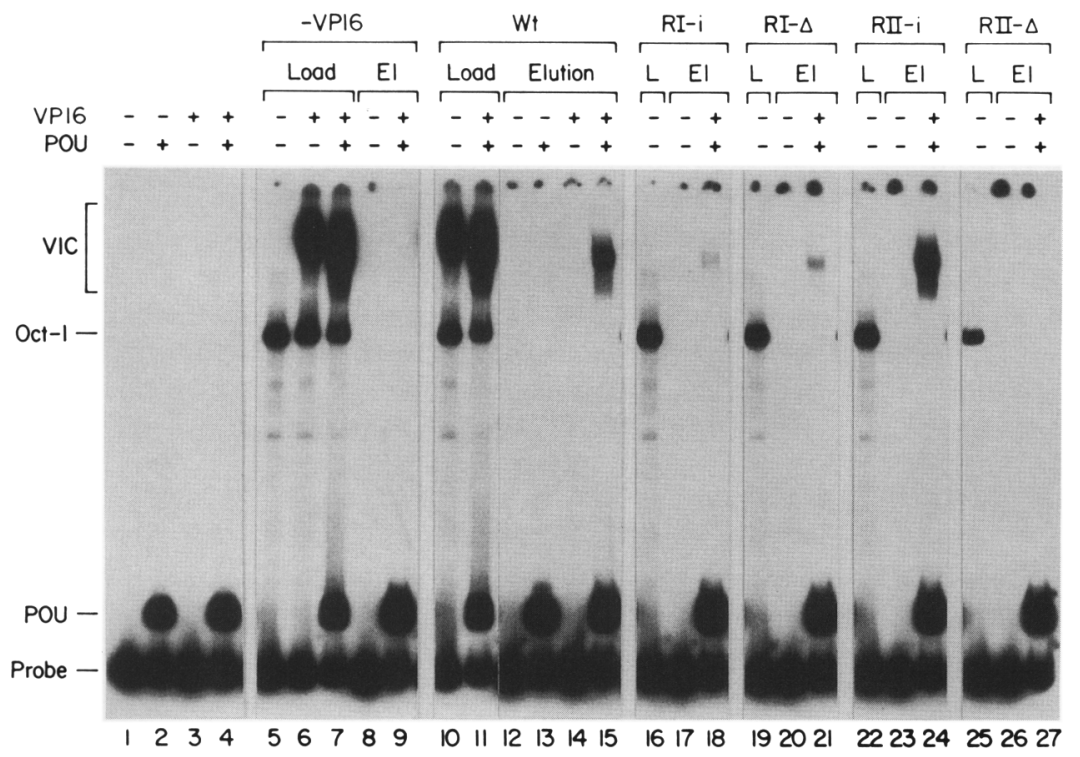

Figure 3. Microprecipitation assay for HCF binding by wild-type and mutant protein A-VP16 fusion proteins monitored by mobilityshift assay. Association of HCF with wild-type and mutant VPl 6 was characterized in a HCF microprecipitation reaction, which was monitored in the mobility-shift assay shown here. The top line indicates whether no VP16 (-VP16), wild-type protein A-VP16 fusion protein $(\mathrm{Wt})$, or one of the four VP16 mutants (RI-i, RI- $\Delta$, RII-i, or RII- $\Delta$ ) was added to the microprecipitation reaction. (Below) The identity of the material assayed from the precipitation reaction, load (L) or elution (El), is indicated. Also shown are indications whether wild-type VP16 and/or Oct-1 POU domain was also added $1+$ or -) to the mobility-shift reaction. The positions of the Oct-1 POU domain complex (POU), HeLa cell Oct-1 complex (Oct-1), and VP16-induced complex (VIC) are shown at left. All reactions were done in parallel, and the different panels are from a single gel. 
domain and VP16 were added together, however, a VP16induced complex did form (lane 15), showing that HCF activity was retained on the beads in a VP16-dependent manner (cf. lanes 9 and 15).

The effects of the four VP16 mutations on HCF recovery are characterized in the last four panels of Figure 3. As expected, all four of the mutants failed to form a VP16-induced complex with HeLa cell extract (cf. lanes $16,19,22$, and 25 with lane 10 l, and as before, the eluates from all four micro-precipitations were devoid of endogenous Oct-1 (lanes 17,20,23,26). Three of the four mutant proteins, however, were still able to retain HCF on the IgG-Sepharose beads, although while the region II insertion mutant RII-i bound HCF at wild-type levels / $\mathrm{cf}$. lanes 24 and 15 ), the region I mutants RI-i and RI- $\Delta$ retained HCF with reduced effectiveness (cf. lanes 18 and 21 with 15). The fourth mutant, RII- $\Delta$, was unable to retain HCF in this assay (lane 27). These results, which are summarized in Figure 2, show that while region I was not required for HCF retention, it may still be involved in HCF binding as mutations within this region decreased the ability of VP16 to associate with HCF. In contrast with these results, deletion of region II reduced HCF retention to undetectable levels in the assay, suggesting that region II of VP16 is required for HCF binding and offering an explanation for why the RII- $\Delta$ protein failed to form an HCF-dependent VP16-induced complex. Because the other three mutant proteins continued to interact with HCF, however, these results also suggest that other interactions required for VP16-induced complex formation have been affected by these mutations. To test this hypothesis, we then assayed the abilities of the four mutant proteins to interact with DNA and the Oct-1 POU domain in the absence of HCF.

As shown in Figure 4, the DNA-binding capacities of wild-type and mutant VPl 6 proteins were tested in the absence or presence of the Oct-1 POU domain, at both $30 \times$ and $60 \times$ VP1 6 concentrations. As expected, wildtype VP16 cooperated with the Oct-1 POU domain to bind the probe at the $30 \times \mathrm{VP} 16$ concentration (lane 4), and the VP16-DNA complex formed at $60 \times$ VP16 concentration (lane 5) was supershifted by the Oct-1 POU domain (lane 6). In contrast, the region $I$ insertion mutant RI-i (lanes 7-10), and the two VP16 deletion mutants RI- $\Delta$ (lanes 11-14) and RII- $\Delta$ (lanes 19-22) did not bind DNA in the absence or presence of the Oct-1 POU domain. The region II insertion mutant RII-i, however, bound DNA on its own as well as, or better than, wildtype VP16 (cf. lanes 3 and 15). Surprisingly, however, it failed to interact productively with the Oct-1 POU domain at both the $30 \times$ and $60 \times$ concentrations. Addition of the Oct-1 POU domain to a reaction containing a $30 \times$ concentration of $\mathrm{RII}-\mathrm{i}$ protein resulted in a reduction of the amount of VP16-DNA complex, rather than in an increase (cf. lanes 15 and 16 with lanes 3 and 4), suggesting that rather than cooperating with the POU domain, the RII-i protein and the POU domain compete for the DNA probe. Competitive behavior was also observed at the $60 \times$ concentration, as the RII-i-DNA complex failed to be supershifted by the Oct-1 POU domain (cf. lanes 6

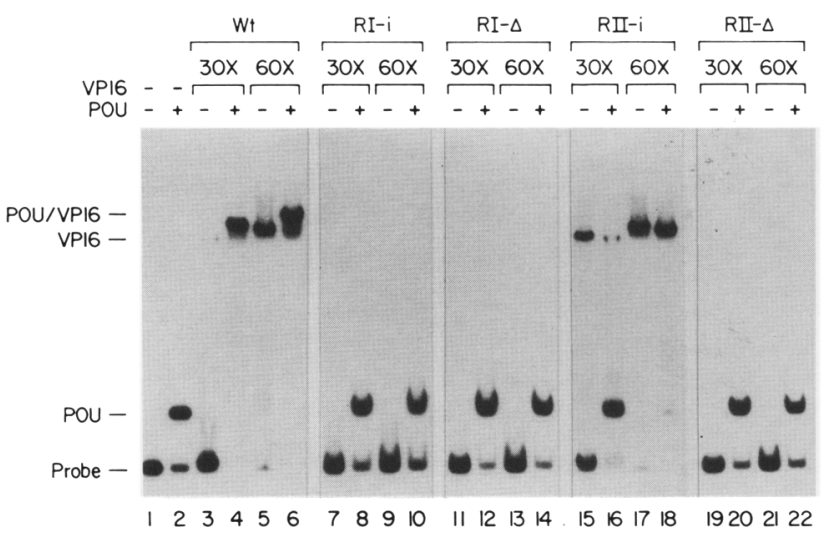

Figure 4. HCF-independent VP16-induced complexes with Oct-1 POU domain and wild-type or mutant protein A-VP16 fusion proteins. Mobility-shift reactions are shown with the OCTA $^{+} \mid$TAATGARAT probe and either wild-type $(\mathrm{Wt})$ or $\mathrm{mu}-$ tant (RI-i, RI- $\Delta$, RII-i, or RII- $\Delta$ ) VP16 proteins and the Oct-1 POU domain. Either no VP16 $(-)$, or $1.5 \mu \mathrm{g}(30 \times)$ or $3 \mu \mathrm{g}(60 \times)$ of the protein A-VP16 fusion proteins were added, and reactions receiving Oct- 1 POU domain are indicated $(+$ and -1 . The positions of the different complexes are shown at left $t_{\text {t }}$ the different panels are from a single gel.

and 181, and instead, the RII-i protein appeared to exclude the POU domain from binding the probe (cf. the POU domain complexes in lanes 16 and 18). These results suggest that the VP16 region interrupted by the RII-i mutation is involved intimately in POU domain association, as it abolishes the strongly cooperative Oct-1 POU domain-VP16 interaction, and reverses it, so that the two proteins compete for the DNA probe.

Interestingly, as summarized in Figure 2, the effects of the RII-i insertion mutation are highly specific. This is because while this mutation dramatically affects the interaction of VP16 with the Oct-1 POU domain, it leaves the DNA- and HCF-binding activities of VP16 virtually unchanged. It is likely that the effects of the RII-i mutation on POU domain association are a consequence of its failure to interact with the Oct-1 homeo domain, because in reactions in which the Oct-1 POU domain was replaced by the Oct-1 homeo domain, the RII-i protein failed to interact productively with the homeo domain itself (data not shown). Along with the effects of the RII-i mutation, the inability of the Oct- 2 homeo domain to interact with VP16 shows that subtle alterations in the interacting surfaces of either the Oct-1 homeo domain or VP16 can have strong effects on complex formation between these two proteins, without affecting other contacts in the VP16-induced complex.

\section{VP16-derived peptides form complexes with DNA and the POU domain}

The observation that the RII-i mutation only affects the ability of VP16 to associate with the Oct-1 POU domain suggests that VP1 6 contains an independent subdomain involved exclusively in this activity. To examine this 
possibility, we have used synthetic peptides derived from regions I and II to test the ability of small segments of VP16 to form complexes with DNA and the Oct-1 POU domain in mobility-shift assays. A synthetic peptide has been used previously to inhibit HCF-dependent VP16-induced complex formation (Haigh et al. 1990), probably by competing with VP16 for either Oct-1 or HCF. The region I (PEPI)- and region II (PEPII)-based peptides extend from amino acids 170 to 202 and 360 to 391 , respectively, and as shown in Figure 2, they encompass the segments of VP16 altered by the RI-i and RII-i insertion mutations. To characterize the specificity of peptide complexes, the activities of a region II peptide containing the 4-amino-acid insertion of the RII-i VP16 mutation (PEPII-i) and of an unrelated peptide containing adenovirus Ela protein sequences were also tested.

As shown in Figure 5A, incubation of $1 \mu \mathrm{g}$ of PEPI with the OCTA $^{+} \mid$TAATGARAT probe resulted in retention of much of the probe at the top of the gel, as well as in the formation of poorly defined PEPI-DNA complexes (lane 1). Addition of increasing amounts of poly[d(I-C)] to the reaction resulted in a decrease in probe-containing PEPI aggregates (lanes 2,3) and in the partial resolution of a PEPI-DNA complex at an intermediate poly $[\mathrm{d}(\mathrm{I}-\mathrm{C})]$ concentration (lane 2). These results show that PEPI binds DNA on its own and that it can produce large probe-containing aggregates. Both of these characteristics are similar to those of intact VP16, which exhibits a similar sensitivity to poly $[\mathrm{d}(\mathrm{I}-\mathrm{C})]$ in its interactions with DNA and also produces poly[d(I-C)]-sensitive probe-containing aggregates (data not shown). PEPI-DNA interactions are comparatively nonspecific, however, because unlike intact VP16, PEPI bound a probe of unrelated sequence with similar affinity (data not shown). Interestingly, the DNA-binding activity of PEPI is consistent with the apparent involvement of region I of VP16 in this activity (summarized in Fig. 2).

The characteristics of PEPI contrast with those of the
Ela-derived peptide, PEPII, and PEPII-i shown in Figure $5 B$. Here, increasing amounts $(1.2,3.8$, or $12 \mu \mathrm{g})$ of each peptide have been incubated with the DNA probe, either alone or together with the Oct-1 POU domain. None of these peptides bound the DNA probe effectively by themselves (lanes 2-10), although in some assays PEPII exhibited a low affinity for DNA (data not shown). However, unlike the Ela peptide (lanes 12-14), PEPII formed a discrete supershift with the Oct-1 POU domain-DNA complex (lanes 15-17). Formation of only a single supershifted complex suggests that the interaction of PEPII with the Oct-1 POU domain is specific, a hypothesis that is underscored by the reduced ability $(\sim 5$ - to 10 -fold) of the mutant peptide, PEPII-i, to form the analogous complex (lanes 18-20). From these experiments we conclude that the VP16 region implicated in homeo domain recognition can also independently form a complex with the POU domain. The activity of PEPII is likely relevant to VP16 function because, as in the full-length protein, the 4-amino-acid insertion mutation interferes with POU-domain association. These results therefore support the idea that this VP16 region contains an independent homeo domain recognition subdomain.

\section{Discussion}

By showing that VP16 can recognize the Oct-l homeo domain in the absence of $\mathrm{HCF}$, we have been able to identify VP16 as the likely target of the Oct-1 homeo domain in a protein-protein interaction that regulates transcription. The properties of the VP16 mutants and synthetic peptides that we have described suggest that the region of VP16 that interacts with the Oct-1 homeo domain comprises an independent subdomain. The existence of such a subdomain is consistent with the modular organization of many transcription factors and suggests that the homeo domain recognition subdomain can be added to a growing list of transcription factor domains

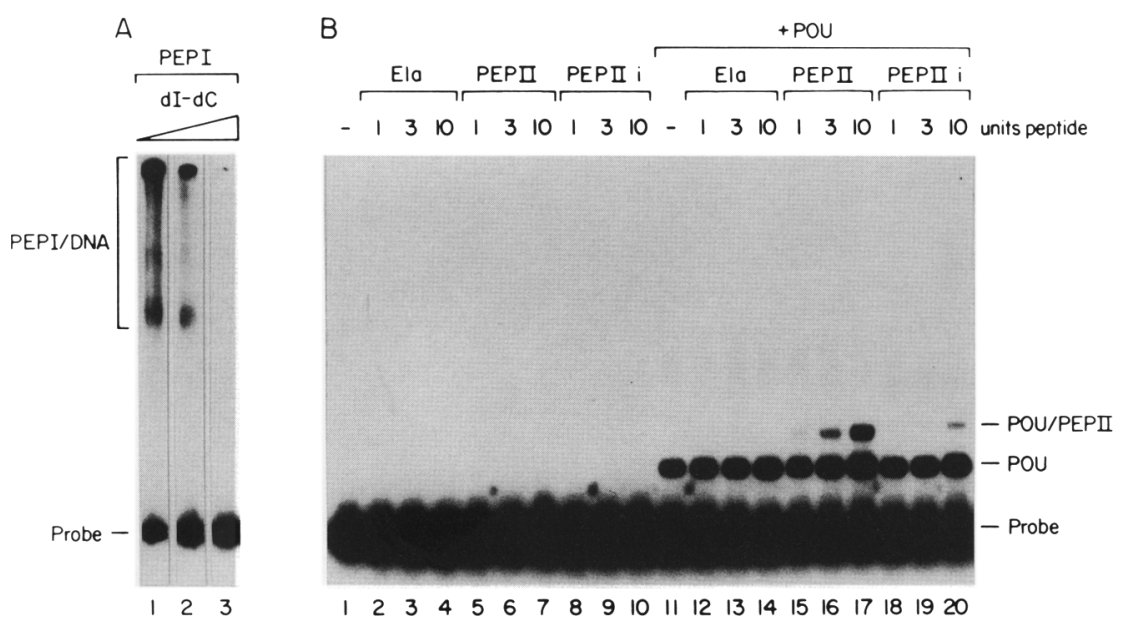

Figure 5. Complexes formed with VP16derived peptides PEPI, PEPII, and PEPII-i. (A) Mobility-shift reactions with the OOCTA $^{+}$|TAATGARAT probe and $1 \mu \mathrm{g}$ of PEPI in reactions containing $0.35 \mu \mathrm{g}$ (lane 1), $0.55 \mu \mathrm{g}$ (lane 2), or $0.75 \mu \mathrm{g}$ (lane 3) of poly[d(I-C)]. The positions of the heterogeneous PEPI-DNA complexes are indicated at left. (B) Mobility-shift reactions are shown with the (OCTA ${ }^{+}$|TAATGARAT probe and $1(1.2 \mu \mathrm{g}), 3(3.8 \mu \mathrm{g})$, or 10 units $\{12 \mu \mathrm{g})$ of the Ela, PEPII, or PEPII-i peptides. Reactions were repeated without and with added Oct- 1 POU domain as indicated. The positions of the Oct-1 POU domain, PEPIIPOU domain, and PEPII-i-POU domain complexes are shown at right. The mobility of the PEPII-i-POU domain complex is slightly decreased compared with that of the PEPII-POU domain complex, probably because of the increased size of PEPII-i. 
that includes various DNA-binding and transcriptional activation domains, and protein dimerization motifs. Like the interactions of the yeast $\alpha 2$ transcription factor with the al and GRM/MCM1 proteins (Goutte and Johnson 1988; Keleher et al. 1988), the characteristics of the VP16-induced complex show how the regulatory activity of a homeo domain-containing transcription factor can be altered by protein-protein interactions. But unlike the yeast system, in which regions flanking the homeo domain are responsible for these interactions, the Oct-1 homeo domain itself directs formation of proteinprotein contacts in the VP16-induced complex.

The VP16 region implicated in homeo domain recognition by the RII-i mutation appears to contain an independent subdomain because the 33-amino-acid peptide derived from it, PEPII, forms a complex with the POU domain. The specificity of PEPII-POU domain interaction is supported by the reduced affinity of the mutant peptide PEPII-i for the POU domain. However, the interactions of PEPII and VP16 with the Oct-1 POU domain differ in two important respects. First, unlike full-length VP16, PEPII fails to discriminate between the Oct-1 and Oct-2 homeo domains (data not shown). Second, the effects of the 4-amino-acid insertion mutation are qualitatively different in PEPII and VP16: Although PEPII-i interacts with the POU domain-DNA complex with reduced effectiveness, when VP16 carries the RII-i mutation it competes with the POU domain for the DNA probe (see Fig. 4). Both of these differences are indicative of a relaxed specificity in PEPII interactions, suggesting that other VP16 regions may be directly involved in Oct-1 association. These differences could also be a consequence, however, of the different environments that these amino acids are subject to within PEPII and VP16. In VP16, interactions with the rest of the protein likely stabilize the conformation of the amino acids in this region, perhaps resulting in increased specificity for complex formation. In addition, the orientation of the PEPII region in VP16 may be constrained by the interaction of VP16 with DNA, which likely fixes the relative positions of the interacting regions of VP16 and the Oct-1 homeo domain.

If VP16 contains a subdomain that recognizes the Oct-1 homeo domain in mobility-shift experiments, why does it fail to interact with Oct-1 in VP16 affinity chromatography experiments (Kristie and Sharp 1990; Xiao and Capone 1990 this study)? One difference between these two assays is that a specific DNA-binding site is present only in the mobility-shift reaction, suggesting that Oct-1-VP16 interactions are DNA binding site dependent. Perhaps in the absence of DNA, the proteinprotein contacts formed between the Oct-1 homeo domain and VP16 are not sufficiently strong to stably bind Oct-1. In this case, the mutual interaction of Oct-1 and VP16 with DNA would serve to stabilize their association. Alternatively, DNA binding by either Oct-1 or VP16 may alter their conformation so as to increase the stability of the protein-protein contacts. Consistent with this hypothesis, comparison of the structures of free and DNA-bound Antennapedia homeo domains de- duced by nuclear magnetic resonance (NMR) has shown that amino acids in helix 2, which in Oct-1 are involved in VP16-induced complex formation (Stern et al. 1989), have different conformations (Otting et al. 1990).

The properties of the four VP16 mutants assayed here also allow us to begin to understand the functional domain structure of VP16. Mutations within region I of VP16 strongly diminish the ability of the protein to interact with DNA in the absence or presence of the Oct-1 POU domain, suggesting that region $I$ is required for DNA binding and that it could be involved directly in this activity. Consistent with this hypothesis, region I contains the most basic region of the VP16 polypeptide, and a synthetic peptide containing amino acids 170-202 of VP16 (PEPI) interacts avidly but nonspecifically with DNA. Mutations within region I also affect HCF association but not as dramatically as deletion of region II does, suggesting that HCF interacts primarily with region II of VP16. Deletion of region II, however, also strongly diminishes VP16-DNA interactions; therefore, it is unclear whether this deletion generally inactivates VP16 by unfolding its native structure. Further studies will be required to clarify the functional roles of these different VP16 regions.

As shown in Figure 6 the homeo domain recognition subdomain, which we have defined as approximately coincident with PEPII, lies near the acidic activation domain of VP16. The PEPII region may contain a 12-aminoacid amphipathic $\alpha$-helix (Lim 1974a,b) which could form as indicated in Figure 6. The RII-i insertion, which selectively disrupts the interaction of VP16 with the Oct-1 POU domain, lies within this putative helix, as do several point and truncation mutations that negatively affect HCF-dependent VP16-induced complex assembly (Greaves and O'Hare 1990). Interestingly, the VP16 ana$\log$ (ORF10 protein) of the HSV-related varicella-zoster virus (VZV) lacks both a region analogous to positions 378-389 of VP16 and a carboxy-terminal acidic domain (Dalrymple et al. 1985). The results of the present studies suggest that a deletion in the 378-389 region should render the protein unable to interact with Oct-1, while the absence of a carboxy-terminal acidic region in the ORF10 protein suggests that it will not activate transcription. Consistent with these expectations, the ORF10 protein fails to form a multiprotein-DNA complex analogous to the VP16-induced complex and also fails to stimulate VZV IE gene transcription (McKee et al. 1990). The correlated presence and absence of homeo domain recognition and transcriptional activation domains, in VP16 and the ORF10 protein, respectively, suggest that these two domains have been acquired together by VP16 during evolution.

It remains to be determined to what extent proteinprotein interactions with homeo domains contribute to cellular transcriptional regulation, particularly during development. Because the homeo domain, which constitutes a largely independent DNA recognition domain, has been so highly conserved, it is tempting to speculate that the region of VP16 involved in homeo domain recognition, which also appears to constitute an indepen- 


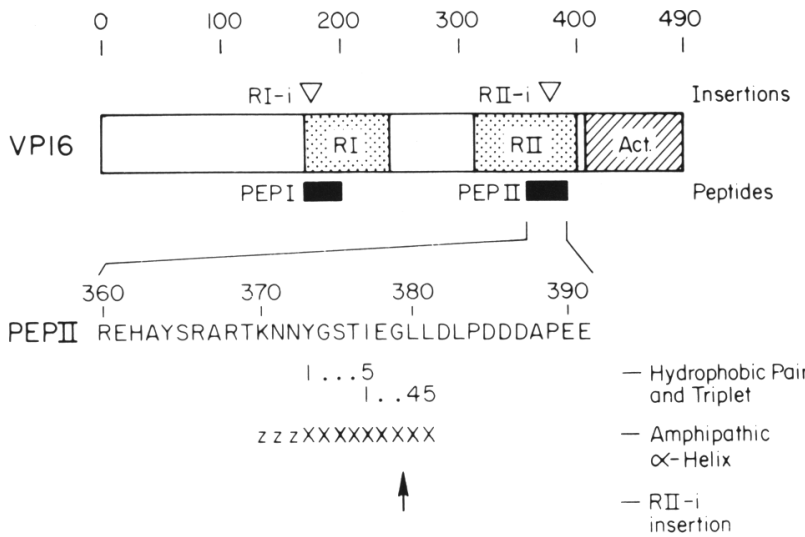

Figure 6. Diagram of VPl6 showing the homeo domain recognition region. The positions of region I (RI; amino acids 173241), region II (RII; amino acids 317-403), and the carboxy-terminal acidic activation domain (Act.) are indicated. The RI-i (in9, at amino acid 177) and RII-i (inl4, at amino acid 379) insertion mutations overlap sequences contained in the peptides PEPI and PEPII, respectively. The sequence of PEPII is shown in the middle. Analysis of this sequence according to the algorithms of Lim (1974a,b; S. Stern and J. Stern, unpubl.), suggests that it is compatible with the formation of an amphipathic $\alpha$-helix extending from amino acid 370 to 381 . As shown beneath the sequence, amino acids 373-381 form an X fragment (Lim $1974 \mathrm{a}, \mathrm{b}$; indicated by XXXXX), which is composed of a hydrophobic 1-5 pair (Y372-I376) linked with a hydrophobic 1-4-5 triplet (I376-L380-L381). The X fragment can be extended on its amino-terminal side to $\mathrm{K} 370$ (indicated by $\mathrm{zzz}$ ), which forms a 1-4 electrostatic pair with Y373. The position of the RII-i in sertion within the putative $\alpha$-helix is shown by the vertical arrow.

dent domain, has likewise been conserved and distributed among a family of cellular transcription factors. Such factors could be considered to be cellular VP16 analogs. Consistent with the existence of such proteins, the HCF activity required for efficient VP16-induced complex assembly has been detected in insect (SF9) cells (Kristie et al. 1989) and in Drosophila embryos (S. Stern, unpubl.). If cellular VP16 analogs do exist they may or may not contain potent transcriptional activation domains. In either case, like VP16, they could function to increase the specificity of their target factors by simultaneously interacting with homeo domains and the DNA sequences flanking homeo domain recognition sites. Such interactions could help to explain how homeo domain proteins, which exhibit overlapping DNA specificities in vitro, give rise to highly specific effects in animals.

\section{Materials and methods}

\section{VP16 and POU-domain expression constructs}

VP16 expression constructs were derived from a Sall fragment encoding amino acids 5-411 of VP16. This Sall fragment, as well as the parental expression vector pRIT2T (Pharmacia), were isolated from the plasmid pRIT65 (Werstuck and Capone
1989 b), which was a kind gift from J. Capone. The 'wild-type' construct containing VP16 residues $5-411$ was produced by ligating the VP16-encoding Sall fragment into pRIT2T. Mutant VP16 constructs were produced by oligonucleotide-directed mutagenesis of the VP16 Sall fragment, which was inserted into the Sall site of pUC1 19. Primers AACTTCTGCGCAAGGATCCGCGCACTGTACCGGTACCT, TATCGAACCGTGTTGGCCGCGTACGCCGAG，TCTACCATCGAGGGAGCGGATCCAAGACTGCTCGATCTCCC, and GGAGGAGCCAGGGGCGGGACACACGCGC were used for the RI-i, RI- $\Delta$, RII-i, and RII- $\Delta$ mutations, respectively, and the mutations were verified by restriction site mapping and DNA sequencing. The mutant Sall fragments were then transferred back into pRIT2T.

DNA fragments encoding the Oct-1 and Oct-1[Ho2] POU domains were generated by polymerase chain reaction (PCR) amplification using plasmids pBSoct- $1^{+}$(Sturm et al. 1988) for the Oct-1 POU domain and $\mathrm{pBS}^{\Delta}{ }^{\Delta}$ oct-1/2)1(N/2/3)1 (Stern et al. 1989) for the Oct-1[Ho2] POU domain. Primers GATCATATGAGCTTGGAGGAGCCC $\left(5^{\prime}\right)$ and ACTGGATCCTCAGTTGATTCTTTTTTC $\left(3^{\prime}\right)$ were used to amplify the POU domain sequences. NdeI and BamHI sites in the primers, as well as an in-frame stop codon in the $3^{\prime}$ primer are underlined. The ATG of the NdeI site at the $5^{\prime}$ end of the fragments is in-frame with the coding sequences. The PCR fragments were cut with NdeI and BamHI, and ligated between the NdeI and BamHI sites of the T7 expression vector pET3b (Studier et al. 1990).

\section{VP16 and POU-domain expression and purification}

Wild-type and mutant VP16 proteins were produced as fusions with staphylococcal protein A in pRIT2T. Expression constructs were transformed into $E$. coli strain N4830 (Pharmacia), which harbors a thermolabile $\lambda$ repressor protein. Half-liter cultures were grown to $A_{600}=0.5$ at $30^{\circ} \mathrm{C}$, induced by temperature shift to $42^{\circ} \mathrm{C}$ by addition of an equal volume of LB media at $56^{\circ} \mathrm{C}$, and expression was allowed to continue for $1-2 \mathrm{hr}$ at $42^{\circ} \mathrm{C}$. The cells were then pelleted and washed, and the pellets were frozen. After thawing on ice for $15 \mathrm{~min}$, the cell pellet from 1 liter of induced culture was resuspended in $50 \mathrm{ml}$ of $50 \mathrm{~mm}$ Tris- $\mathrm{HCl}(\mathrm{pH} 7.6), 250 \mathrm{~mm} \mathrm{NaCl}, 10 \mathrm{~mm}$ EDTA, $13 \%$ sucrose, $0.1 \% \mathrm{NP}-40$, and $250 \mu \mathrm{g} / \mathrm{ml}$ of lysozyme and incubated on ice for $30 \mathrm{~min}$. Cell debris was pelleted at $100,000 \mathrm{~g}$ for $1.5 \mathrm{hr}$, and the supernatant was added to $2 \mathrm{ml}$ of IgG-Sepharose (Pharmacia), which had been equilibrated with TST buffer [50 mM Tris$\mathrm{HCl}(\mathrm{pH} 7.6), 150 \mathrm{~mm} \mathrm{NaCl}, 0.05 \%$ Tween 20$)$ as recommended by the manufacturer. After mixing end over end for $1 \mathrm{hr}$ at $4^{\circ} \mathrm{C}$, the beads were pelleted with a low-speed spin, and $90 \%$ of the supernatant was removed. The beads were resuspended in the remaining supernatant and transferred to a 5-ml Dispo-column (Bio-Rad). After washing with $20 \mathrm{ml}$ of TST buffer, followed by $4 \mathrm{ml}$ of $5 \mathrm{mM} \mathrm{NH}_{4} \mathrm{Ac}$ (pH 5.0), proteins were eluted with $0.5 \mathrm{M}$ HAc (pH 3.6) and desalted over a PD10 column (Pharmacia) into $50 \mathrm{~mm}$ Tris- $\mathrm{HCl}$ ( $\mathrm{pH} 7.6), 100 \mathrm{~mm} \mathrm{NaCl}, 1 \mathrm{~mm}$ EDTA, $1 \mathrm{~mm}$ DTT, and 10\% glycerol buffer. Expression levels and purity were monitored by SDS-PAGE, followed by silver staining, and by Western blotting with radiolabeled IgG. Typically, $\sim 2 \mathrm{mg}$ of fusion protein per liter of induced culture was obtained for the wild-type and RII-i VP16 proteins, whereas $\sim 10$-fold less was obtained for the RI-i, RI- $\Delta$, and RII- $\Delta$ mutants. Proteins expressed at lower levels were concentrated to wild-type protein levels with Centricon concentrators (Amicon). The final normalized concentrations of the wild-type and mutant proteins were verified by Western blotting.

The Oct-1 and Oct-1[Ho2] POU domains were expressed in $\mathrm{BL} 21$ (DE3) cells. Half-liter cultures were grown at $37^{\circ} \mathrm{C}$ to 
$A_{600}=0.8$, transferred to $30^{\circ} \mathrm{C}$, and induced with 0.4 mM IPTG. After several hours, the cells were pelleted and washed, and the cell pellets were frozen. Pellets were resuspended in $50 \mathrm{ml}$ of 50 $\mathrm{mm}$ Tris- $\mathrm{HCl}$ ( $\mathrm{pH} 7.6), 100 \mathrm{~mm} \mathrm{NaCl}, 10 \mathrm{~mm}$ EDTA, 1 mM DTT, $0.1 \% \mathrm{NP}-40,10 \%$ glycerol, and $250 \mu \mathrm{g} / \mathrm{ml}$ of lysozyme and incubated on ice for $30 \mathrm{~min}$. Cell debris was pelleted at $100,000 \mathrm{~g}$ for $\mathrm{l} \mathrm{hr}$, and soluble POU-domain proteins were purified by DNA affinity chromatography (Kadonaga and Tjian 1986). Proteins were eluted with $50 \mathrm{~mm}$ Tris- $\mathrm{HCl}\langle\mathrm{pH} 7.6\}, 1 \mathrm{M} \mathrm{NaCl}, 1$ mM EDTA, 1 mM DTT, and 10\% glycerol buffer.

\section{Mobility-shift assay for HCF-independent VP16-induced complexes}

Protein-DNA binding reactions were performed in $12.5-\mu \mathrm{l}$ reactions containing $20 \mathrm{mM} \mathrm{K}-\mathrm{HEPES}$ ( $\mathrm{pH} 7.9$ ), $60 \mathrm{mM} \mathrm{KCl}, 2 \mathrm{~mm}$ EDTA, $0.5 \mathrm{~mm}$ DTT, $0.03 \% \mathrm{NP}-40,2 \%$ Ficoll $400,0.1 \mathrm{mg} / \mathrm{ml}$ of BSA, and $0.35 \mu \mathrm{g}$ of unsonicated poly[d(I-C)] (Pharmacia). Approximately $0.5 \mathrm{ng}$ of POU proteins and the indicated amounts of protein A-VP16 fusion proteins were incubated with the probe for $30 \mathrm{~min}$ at $30^{\circ} \mathrm{C}$, and half the reaction $(6 \mu l)$ was carefully layered onto the bottom of the well of a $6 \%, 19: 1$ acrylamide/bis-acrylamide, $0.25 \times \mathrm{TBE}$ gel, which was run at 12 $\mathrm{V} / \mathrm{cm}$ for $\sim 3 \mathrm{hr}$ at room temperature. Probes, containing wildtype and mutant TAATGARAT elements derived from the HSV ICPO promoter (Gerster and Roeder 1988) inserted into the pUC1 19 polylinker, were $3^{\prime}$ end-labeled with Klenow fragment and $\alpha-{ }^{32} \mathrm{P}$-labeled dNTPs. Formation and/or observation of HCF-independent VP16-induced complexes appears to depend on the characteristics of the mobility-shift gel, as these complexes have not been observed with 4\% 39:1 acrylamide/bisacrylamide gels.

\section{HCF microprecipitation assay}

Fifty microliters of $7 \mathrm{mg} / \mathrm{ml} \mathrm{HeLa} \mathrm{cell} \mathrm{nuclear} \mathrm{extract} \mathrm{in} \mathrm{buffer}$ $\mathrm{D}$ (Dignam et al. 1983) and $1 \mu \mathrm{l}$ of $\sim 500 \mu \mathrm{g} / \mathrm{ml}$ of wild-type or mutant VP16 protein were combined and incubated for $30 \mathrm{~min}$ at $30^{\circ} \mathrm{C}$. Reactions were then centrifuged at $4^{\circ} \mathrm{C}$ for $10 \mathrm{~min}$ at $16,000 \mathrm{~g}$, and the supernatants were added to $20 \mu \mathrm{l}$ of IgG-Sepharose beads (Pharmacia) that had been equilibrated in TST buffer. The beads were mixed end over end for $30 \mathrm{~min}$, pelleted, and washed twice with $200 \mu l$ of TST. The beads were then washed three times with $50 \mu \mathrm{l}$ of high-salt buffer [50 mM Tris$\mathrm{HCl}(\mathrm{pH} 7.6), 1 \mathrm{M} \mathrm{KCl}, 1 \mathrm{~mm}$ EDTA, $1 \mathrm{~mm}$ DTT, and $10 \%$ glycerol]. Because of dilution by the remaining wash buffer, the first two high-salt washes produced intermediate salt levels that did not selectively elute VP16-associated HCF. The eluate from the third high-salt wash, however, was devoid of nonspecifically retained $\mathrm{HCF}$ and was used to characterize VP16-specific retention of HCF activity in subsequent mobility-shift reactions containing $0.1-0.5 \mathrm{ng}$ of Oct-1 POU domain and $50 \mathrm{ng}$ of wild-type protein A-VP16 fusion protein. In some experiments, as in the one shown in Figure 3, $1 \mu \mathrm{g}$ of the region I peptide, PEPI, was added to the mobility-shift reaction because it enhances formation of the VP16-induced complex. The basis for this effect is not known, but the same qualitative results have been obtained with and without the addition of PEPI. Mobility-shift reactions were carried out essentially as described in Stern et al. (1989) except that the final salt concentration was $100 \mathrm{~mm}$ instead of $60 \mathrm{~mm}$. Complexes were resolved with 4\%, 39:1 acrylamide/ bis-acrylamide gels in $0.25 \times \mathrm{TBE}$.

Synthetic Peptides

Peptides PEPI /CTVLANFCSALYRTLRASVRQLHRQAHMRGRDRD), PEPII (CREHAYSRARTKNNYGSTIEGLLDLPD-
DDAPEE), PEPII-i (CREHAYSRARTKNNYGSTIEGADPRLLD LPDDDAPEE) (the RII-i insertion is underlined), and Ela (HFEPPTVHEVYDVQPQVIEVTSHDAGFPPS), which was the kind gift of Nick Dyson and Ed Harlow, were synthesized on an Applied Biosystems 430A peptide synthesizer using $\mathrm{N}-\alpha-\mathrm{Boc}$ amino acid derivatives. In addition to VP16 sequences, peptides PEPI, PEPII, and PEPII-i contain amino-terminal cysteines. The peptides were removed from the resin using liquid HF, precip itated with ethyl ether, and purified by two rounds of reversephase high performance liquid chromatography (HPLC). The structures of the final products were confirmed by plasma desorption mass spectrometry and analytical HPLC. Lyophilized peptides were resuspended in water, and final peptide concentrations were determined by amino acid analysis. The activities of the peptides were characterized in mobility-shift assays using conditions described above for HCF-independent VP16-induced complexes.

\section{Acknowledgments}

We thank J. Capone for the VP16 expression plasmid pRIT65 prior to publication; G. Binns, M. Meneilly, and D. Marshak for synthesis and preparation of the synthetic peptides; N. Dyson and E. Harlow for the Ela-derived peptide; T. Kristie and $\mathrm{P}$. Sharp for communicating results prior to publication; N. Her nandez, B. Stillman, M. Tanaka, A. Wilson, and S. Bell for improvements to the manuscript; J. Reader for help with typing; and J. Duffy, M. Ockler, and P. Renna for artwork. S.S. was supported by a postdoctoral fellowship from the National Institutes of Health. This work was supported by U.S. Public Health Services grant CA-13106 from the National Cancer Institute.

The publication costs of this article were defrayed in part by payment of page charges. This article must therefore be hereby marked "advertisement" in accordance with 18 USC section 1734 solely to indicate this fact.

\section{References}

Ace, C.I., M.A. Dalrymple, F.H. Ramsay, V.G. Preston, and C.M. Preston. 1988. Mutational analysis of the herpes simplex virus type 1 trans-inducing factor Vmw65. I. Gen. Virol 69: 2595-2605.

apRhys, C.M.J., D.M. Ciufo, E.A. O'Neill, T.J. Kelly, and G.S Hayward. 1989. Overlapping octamer and TAATGARAT motifs in the VF65 response elements in herpes simplex virus immediate-early promoters represent independent binding sites for cellular nuclear factor III. J. Virol. 63: 2798-2812.

Batterson, W. and B. Roizman. 1983. Characterization of the herpes simplex virion-associated factor responsible for the induction of $\alpha$ genes. /. Virol. 46: 371-377.

Campbell, M.E.M., J.W. Palfreyman, and C.M. Preston. 1984 Identification of herpes simplex virus DNA sequences which encode a trans-acting polypeptide responsible for stimulation of immediate early transcription. I. Mol. Biol. 180: $1-19$.

Clerc, R.G., L.M. Corcoran, J.H. LeBowitz, D. Baltimore, and P.A. Sharp. 1988. The B-cell-specific Oct-2 protein contains POU box- and homeo box-type domains. Genes \& Dev. 2: $1570-1581$.

Cousens, D.J., R. Greaves, C.R. Goding, and P. O'Hare. 1989. The C-terminal 79 amino acids of the herpes simplex virus regulatory protein, Vmw65, efficiently activates transcription in yeast and mammalian cells in chimeric DNA-binding proteins. $E M B O / .8: 2337-2342$.

Dalrymple, M.A., D.J. McGeoch, A.J., Davison, and C.M. Pres- 
ton. 1985. DNA sequence of the herpes simplex virus type 1 gene whose product is responsible for transcriptional activation of immediate early promoters. Nucleic Acids Res. 13: 7865-7879.

Dignam, J.D., R.M. Lebovitz, and R.G. Roeder. 1983. Accurate transcription by RNA polymerase II in a soluble extract from isolated mammalian nuclei. Nucleic Acids Res. 11: 14751489.

Gerster, T. and R.G. Roeder. 1988. A herpesvirus trans-activating protein interacts with transcription factor OTF-1 and other cellular proteins. Proc. Natl. Acad. Sci. 85: 6347-6351.

Gibson, G., A. Schier, P. LeMotte, and W.J. Gehring. 1990. The specificities of sex combs reduced and antennapedia are defined by a distinct portion of each protein that includes the homeo domain. Cell 62: 1087-1103.

Goding, C.R. and P. O'Hare. 1989. Herpes simplex virus Vmw65-octamer binding protein interaction: A paradigm for combinatorial control of transcription. Virology 173: 363367.

Goutte, C. and A.D. Johnson. 1988. al Protein alters the DNA binding specificity of $\alpha 2$ repressor. Cell 52: 875-882.

Greaves, R.F. and P. O'Hare. 1989. Separation of requirements for protein-DNA complex assembly from those for functional activity in the herpes simplex virus regulatory protein Vmw65. J. Virol. 63: 1641-1650.

- 1990. Structural requirements in the herpes simplex virus type 1 transactivator Vmw65 for interaction with the cellular octamer-binding protein and target TAATGARAT sequences. J. Virol. 64: 2716-2724.

Guarente, L., A. Nye, A. Hochschild, and M. Ptashne. 1982. Mutant $\lambda$ phage repressor with a specific defect in its positive control function. Proc. Natl. Acad. Sci. 79: 2236-2239.

Haigh, A., R. Greaves, and P. O'Hare. 1990. Interference with the assembly of a virus-host transcription complex by peptide competition. Nature 344: 257-259.

Hawley, D.K. and W.R. McClure. 1983. The effect of a lambda repressor mutation on the activation of transcription initiation from the lambda $\mathrm{P}_{\mathrm{RM}}$ promoter. Cell 32: 327-333.

Hayashi, S. and M.P. Scott. 1990. What determines the specificity of action of Drosophila homeo domain proteins. Cell 63: 883-894.

Herr, W., R.A. Sturm, R.G. Clerc, L.M. Corcoran, D. Baltimore, P.A. Sharp, H.A. Ingraham, M.G. Rosenfeld, M. Finney, G. Ruvkun, and H.R. Horvitz. 1988. The POU domain: A large conserved region in the mammalian pit-1, oct-1, oct-2, and Caenorhabditis elegans unc-86 gene products. Genes \& Dev. 2: 1513-1516.

Hochschild, A., N. Irwin, and M. Ptashne. 1983. Repressor structure and the mechanism of positive control. Cell 32: 319-325.

Kadonaga, J.T. and R. Tjian. 1986. Affinity purification of sequence-specific DNA binding proteins. Proc. Natl. Acad. Sci. 83: 5889-5893.

Katan, M., A. Haigh, C.P. Verrijzer, P.C. van der Vliet, and P. O'Hare. 1990. Characterization of a cellular factor which interacts functionally with Oct- 1 in the assembly of a multicomponent transcription complex. Nucleic Acids Res. 18: $6871-6880$.

Keleher, C.A., C. Goutte, and A.D. Johnson. 1988. The yeast cell-type-specific repressor $\alpha 2$ acts cooperatively with a noncell-type-specific protein. Cell 53: 927-936.

Kissinger, C.R., L. Beishan, E. Martin-Bianco, T.B. Kornberg, and C.O. Pabo. 1990. Crystal structure of an engrailed homeo domain-DNA complex at $2.8 \AA$ resolution: A framework for understanding homeo domain-DNA interactions. Cell 63: 579-590.
Kristie, T.M. and P.A. Sharp. 1990. Interactions of the Oct-1 POU subdomains with specific DNA sequences and with the HSV $\alpha$-trans-activator protein. Genes \& Dev. 4: 23832396.

Kristie, T.M., J.H. LeBowitz, and P.A. Sharp. 1989. The octamerbinding proteins form multi-protein-DNA complexes with the HSV $\alpha$ TIF regulatory protein. EMBO I. 8: 4229-4238.

Kuziora, M.A. and W. McGinnis. 1989. A homeo domain substitution changes the regulatory specificity of the deformed protein in Drosophila embryos. Cell 59: 563-571.

Lim, V.I. 1974a. Structural principles of the globular organization of protein chains. A stereochemical theory of globular protein secondary structure. I. Mol. Biol. 88: 857-872.

. 1974b. Algorithms for prediction of $\alpha$-helical and $\beta$-structural regions in globular proteins. J. Mol. Biol. 88: $873-894$.

Malicki, J., K. Schughart, and W. McGinnis. 1990. Mouse Hox2.2 specifies thoracic segmental identity in Drosophila embryos and larvae. Cell 63: 961-967.

Mann, R.S. and D.S. Hogness. 1990. Functional dissection of ultrabithorax proteins in D. melanogaster. Cell 60: 597-610.

Marsden, H.S., M.E.M. Campbell, L. Haarr, M.C. Frame, D.S. Parris, M. Murphy, R.G. Hope, M.T. Muller, and C.M. Preston. 1987. The 65,000-M $\mathrm{M}_{\mathrm{r}}$ DNA-binding and virion transinducing proteins of herpes simplex virus type 1. I. Virol. 61: 2428-2437.

McGinnis, N., M.A. Kuziora, and W. McGinnis. 1990. Human Hox-4.2 and Drosophila Deformed encode similar regulatory specificities in Drosophila embryos and larvae. Cell 63: 969976.

McKee, T., G.H. Disney, R.D. Everett, and C.M. Preston. 1990. Control of expression of the varicella-zoster virus major immediate-early gene. I. Virol. 71: 897-906.

McKnight, J.L.C., T.M. Kristie, and B. Roizman. 1987. Binding of the virion protein mediating $\alpha$ gene induction in herpes simplex virus 1 -infected cells to its cis site requires cellular proteins. Proc. Natl. Acad. Sci. 84: 7061-7065.

O'Hare, P. and C.R. Goding. 1988. Herpes simplex virus regulatory elements and the immunoglobulin octamer domain bind a common factor and are both targets for virion transactivation. Cell 52: 435-445.

O'Hare, P.O., C.R. Goding, and A. Haigh. 1988. Direct combinatorial interaction between a herpes simplex virus regulatory protein and a cellular octamer-binding factor mediates specific induction of virus immediate-early gene expression. EMBO 1. 7: 4231-4238.

Otting, G., Y.Q. Qian, M. Billeter, M. Muller, M. Affolter, W.J. Gehring, and K. Wuthrich. 1990. Protein-DNA contacts in the structure of a homeo domain-DNA complex determined by nuclear magnetic resonance spectroscopy in solution. EMBO I. 9: 3085-3092.

Preston. C.M., M.C. Frame, and M.E.M. Campbell. 1988. A complex formed between cell components and an HSV structural polypeptide binds to a viral immediate early gene regulatory DNA sequence. Cell 52: 425-434.

Pruijn, G.J.M., W. van Driel, and P.C. van der Vliet. 1986. Nuclear factor III, a novel sequence-specific DNA-binding protein from HeLa cells stimulating adenovirus DNA replication. Nature 322: 656-659.

Qian, Y.Q., M. Billeter, G. Otting, M. Muller, W.J. Gehring, and K. Wuthrich. 1989. The structure of the Antennapedia homeodomain determined by NMR spectroscopy in solution: Comparison with prokaryotic repressors. Cell 59: 573-580.

Sadowski, I., J. Ma, S. Triezenberg, and M. Ptashne. 1988. GAL4VP16 is an unusually potent transcriptional activator. $\mathrm{Na}$ ture 335: 563-564. 
Staudt, L.M., H. Singh, R. Sen, T. Wirth, P.A. Sharp, and D. Baltimore. 1986. A lymphoid-specific protein binding to the octamer motif of immunoglobulin genes. Nature 323: 640643.

Stern, S., M. Tanaka, and W. Herr. 1989. The oct-1 homeodomain directs formation of a multiprotein-DNA complex with the HSV transactivator VP16. Nature 341: 624-630.

Studier, F.W., A.H. Rosenberg, J.J. Dunn, and J.W. Dubendorff. 1990. Use of T7 RNA polymerase to direct expression of cloned genes. Methods Enzymol. 185: 60-89.

Sturm, R.A. and W. Herr. 1988. The POU domain is a bipartite DNA-binding structure. Nature 336: 601-604.

Sturm, R.A., G. Das, and W. Herr. 1988. The ubiquitous octamer-binding protein Oct-1 contains a POU domain with a homeo box subdomain. Genes \& Dev. 2: 1582-1599.

Tanaka, M. and W. Herr. 1990. Differential transcriptional activation by Oct-1 and Oct-2: Interdependent activation domains induce Oct-2 phosphorylation. Cell 60: 375-386.

Tanaka, M., U. Grossniklaus, W. Herr, and N. Hernandez. 1988. Activation of the U2 snRNA promoter by the octamer motif defines a new class of RNA polymerase II enhancer elements. Genes \& Dev. 2: 1764-1778.

Triezenberg, S.J., R.C. Kingsbury, and S.L. McKnight. 1988. Functional dissection of VP16, the trans-activator of herpes simplex virus immediate early gene expression. Genes \& Dev. 2: 718-729.

Werstuck, G. and J.P. Capone. 1989a. Mutational analysis of the herpes simplex virus trans-inducing factor Vmw65. Gene 75: 213-224.

- 1989b. Identification of a domain of the herpes simplex virus trans-activator Vmw65 required for protein-DNA complex formation through the use of protein $A$ fusion proteins. I. Virol. 63: 5509-5513.

Xiao, P. and J.P. Capone. 1990. A cellular factor binds to the herpes simplex virus type 1 transactivator Vmw65 and is required for Vmw65-dependent protein-DNA complex assembly with Oct-1. Mol. Cell. Biol. 10: 4974-4977. 


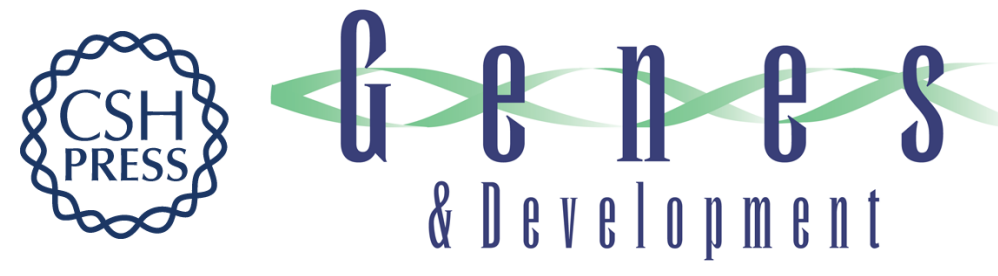

\section{The herpes simplex virus trans-activator VP16 recognizes the Oct-1 homeo domain: evidence for a homeo domain recognition subdomain.}

S Stern and W Herr

Genes Dev. 1991, 5:

Access the most recent version at doi:10.1101/gad.5.12b.2555

References This article cites 53 articles, 17 of which can be accessed free at:

http://genesdev.cshlp.org/content/5/12b/2555.full.html\#ref-list-1

License

Email Alerting Receive free email alerts when new articles cite this article - sign up in the box at the top Service right corner of the article or click here.

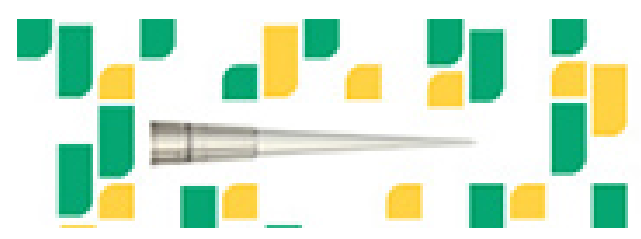

Focused on your science. 